\title{
SUBCLINICAL HYPOTHYROIDISM AND ITS CORRELATION WITH LIPID PROFILE AND HISTOPATHOLOGICAL CHANGES OF THE THYROID GLAND OF CAMELS (CAMELUS DROMEDARIUS)
}

\author{
SAMERA A. SANOUSI ${ }^{1}$; MOHAMED H. RATIB ${ }^{2}$; SAHAR A. ABOU EL-WAFA ${ }^{3}$; LAMIAA M. \\ ABOU EL-HASSAN ${ }^{4}$ and MOSTAFA A. SALEH ${ }^{4}$ \\ ${ }^{1}$ Animal Health Research Institute, El-Dakhla Branch \\ ${ }^{2}$ Animal Health Research Institute, Assiut Branch \\ ${ }^{3}$ Department of Internal Medicine, Fac. of Vet. Med. Assiut Univ. \\ ${ }^{4}$ Animal Health Research Institute, El-Kharga Branch.
}

Received: 20 October 2016;

Accepted: 23 November 2017

\begin{abstract}
Hypothyroidism is the most common type of thyroid disorder in animals. The present study aimed to determine the relationship between the subclinical abnormalities of the thyroid gland and blood serum lipid contents in camels. Slaughtered male camels (156 camels, 4-6 years old) in Assiut abattoirs were thoroughly examined preand postmortem for the thyroid abnormalities. Blood was sampled from each camel for serum separation. Before slaughtering, no visible changes in the neck region were observed. According to growth and histopathological examinations of the thyroid gland, blood sera of 28 camels were selected and classified into 3 groups. The first group (G1, N=10) suffered from simple goiter; the gland was normal in size, but firm with irregular surface. Follicles were mildly irregular in shape with slight hyperplasia of the epithelial cells. The second (G2, N=8) suffered from non-toxic nodular goiter, lobs showed nodules, which appear typically as a solitary, spherical, encapsulated lesions. Follicles were diffusely enlarged, dilated with varying sizes and hyperplastic epithelium. The third was a control group (G3, N=10) with normal thyroid gland. The recorded values of blood serum thyroid hormones $(\mathrm{nmol} / \mathrm{l})$ were $1.21 \pm 0.04$ for $\mathrm{T}_{3}$ and $79.6 \pm 2.14$ for $\mathrm{T}_{4}$. These values did not change in camels with simple goiter, but decreased $(\mathrm{P}<0.01)$ in those with non-toxic nodular goiter when compared with euthyroid camels. Total lipids and triglycerides increased in camels with simple goiter $(\mathrm{P}<0.05)$, but in camels with nodular goiter there were a higher values $(\mathrm{P}<0.01)$ in total lipids, cholesterol and triglycerides compared with healthy camels. As a conclusion, thyroid disorders and the concomitant hypothyroidism is associated with lipid disturbances that are characterized by elevated total lipids, triglycerides and cholesterol levels in camels with non-toxic nodular goiter.
\end{abstract}

Key Words: Subclinical Hypothyroidism, Lipid Profile, Histopathology Changes, Thyroid Gland, Camels.

\section{INTRODUCTION}

The main functions of the thyroid gland are the trapping of iodine, synthesis, storage and release of the thyroid hormones, thyroxine $\left(\mathrm{T}_{4}\right)$ triiodothyronine $\left(\mathrm{T}_{3}\right)$ which controlled by thyrotrophic hormone (Kaneko, 2008). Thyroid hormones are known as important modulators of general metabolism. These hormones regulate energy metabolism in which carbohydrates and lipids are the major constituents by increasing lipolysis in adipose tissue and stimulating lipogenesis by increasing the activities of some enzymes (Eshratkhah et al., 2009 and Mohebbi-Fani et al., 2009).

Corresponding author: Dr. MOHAMED H. RATIB

E-mail address: M_M_mohmmed77@yahoo.com

Present address: Animal Health Research Institute, Assiut Branch.
Goitre may be defined as any enlargement of the thyroid gland, which is not due to inflammation or malignancy. Jones et al. (1997) classified goiter in animals into three main categories. The first is simple goiter (hyperplastic goiter, colloid goiter and diffuse non-toxic goiter), the second is non-toxic nodular goiter (nodular thyroid hyperplasia), and the third is exophthalmic goiter (goiter of hyperthyroidism, toxic goiter and Graves' disease).

Hypothyroidism is the most common type of thyroid disorder in animals, caused by defective thyroglobulin synthesis. The occurrence of the disease is widespread. It was recorded in human in Upper Egypt (Abdou et al., 1967), in animals and man in most parts of Africa (Schillhorn and Loeffler, 1990 and Bourdoux et al., 1996) and in different parts of the world (Brody, 1999). The prevalence rates of 
goiter in camels may exceed 20\% (Abu Damir et al., 1990).

Under field domain practice, the judgment of the thyroid state is depending mainly on the values of thyroid hormones $\left(\mathrm{T}_{3}, \mathrm{~T}_{4}\right)$ and thyroid stimulating hormone (TSH) in the serum. The determination of serum or plasma levels of TSH is recognized as a sensitive method in the diagnosis of hypothyroidism in human. Cross-reactivates of the anti-human TSH are insufficient to be used as an accurate diagnostic test in farm animals and there is no available or commercial anti-sera TSH for animals by RAI or ELISA (except for companion animals) until now (Latimer, 2011). Therefore, we depended in this study on determination of thyroid hormones $\left(\mathrm{T}_{3}, \mathrm{~T}_{4}\right)$ and the pathology of the thyroid gland in the diagnosis of subclinical hypothyroidism in the camel. In addition, the significance of dyslipidemia in subclinical hypothyroidism in livestock remains controversial.

The aim of this work was the estimation the lipogram in blood serum and its relation to subclinical hypothyroidism of the dromedary camels.

\section{MATERIALS AND METHODS}

A total of 156 male camels (4-6 years old) admitted for slaughtering in Assiut abattoirs during the period of November 2013 to march 2014 were thoroughly examined for the thyroid gland abnormalities in the neck region. Blood was drained from the jugular vein of the examined camels for serum separation. Before slaughtering, clinical examination revealed no visible changes in the thyroid region. However, the thyroid gland could be palpated in 8 camels. After slaughtering, the thyroid gland was will grossly examined. Tissues for histopathology were fixed in $10 \%$ neutral, buffered formalin, embedded in paraffin, sectioned at $5 \mu$ and stained with hematoxylin-eosin.

According to the macroscopic and microscopic findings of the thyroid gland, sera of 28 animals of the examined camels were classified into 3 groups: The first group $(\mathrm{G} 1, \mathrm{~N}=10)$ suffered from simple goiter, the second $(\mathrm{G} 2, \mathrm{~N}=8)$ suffered from non-toxic nodular goiter, while the third was a control group $(\mathrm{G} 3, \mathrm{~N}=10)$ with normal thyroid gland.

Blood serum $\mathrm{T}_{3}$ and $\mathrm{T}_{4}$ were estimated by standard ELISA techniques using test kits (Bio-Merieux, 69280 Marcy, L'Etoile, France) according to manufacture instructions. Total serum lipid, total cholesterol (TC) and triglycerides (TG) were determined by enzymatic colorimetric assay by using commercial test kits (Sclavo diagnostics, Italy) after the methods described by Stein (1986), Zlatkis and Zak (1969) and Fletcher (1968) respectively.

\section{RESULTS}

\section{Pathological findings in the thyroid gland}

1- Simple goiter:

A- Grossly: thyroid gland was about normal in size, but firm with irregular surface with dark red coloration. Transverse section of the thyroid gland revealed fatty tissues and brown gelatinous colloid.

B- Microscopic appearance: several follicles were mildly irregular in shape with slight hyperplasia of the epithelial cells and little pale vacuolated colloid. Some follicles were lined by flattened epithelium. Smaller follicles have more columnar epithelium. Also asymmetric papillary projections of crowded columnar cells were found (Fig. 1B, 2 A,B).

2- Non-toxic nodular goiter (nodular hyperplasia):

A- Grossly: thyroid gland was firm, uni or bilaterally enlarged. Lobs showed one or more nodules, which appeared typically as a solitary, semi-spherical, encapsulated lesion that was well demarcated from the surrounding thyroid (Fig 1A). Transverse section of the thyroid gland revealed fibrosis.

B- Microscopic appearance: follicles were diffusely enlarged and dilated with papillary projections into the follicles (Fig 3A). This future is accompanied by degenerated follicles, connective tissue proliferation and flattened to hyperplastic epithelium (Fig,3B).

\section{Levels of serum thyroid hormones:}

The recorded over all mean values of blood serum triiodothyronine $\left(\mathrm{T}_{3}\right)$ and thyroxine $\left(\mathrm{T}_{4}\right)$ concentrations $(\mathrm{nmol} / \mathrm{l})$ in dromedary camels are illusterated in tab. 1, Fig.1. The mean values were $1.21 \pm 0.04,1.11 \pm 0.05$ and $0.89 \pm 0.03$ for $\mathrm{T}_{3}$, and $79.6 \pm 2.14,76.4 \pm 2.34$ and $68.1 \pm 1.25$ for $\mathrm{T}_{4}$ in euthyroid, simple goiter and nontoxic nodular goiter, respectively. These values did not change in camels with simple goiter, but decreased $(\mathrm{P}<0.01)$ in those with non-toxic nodular goiter when compared with euthyroid camels.

\section{Levels of serum lipids:}

The recorded over all mean values of blood serum total lipids $(\mathrm{mg} / \mathrm{dl})$, cholesterol $(\mathrm{mmol} / \mathrm{l})$ and triglycerides $(\mathrm{mmol} / \mathrm{l})$ in dromedary camels are illusterated in Tab.1 and Fig.2. The mean values were $351.1 \pm 6.7,379.4 \pm 5.6$ and $455.2 \pm 5.9$ for total lipids, $0.91 \pm 0.03,0.94 \pm 0.03$ and $1.21 \pm 0.04$ for cholesterol, and $0.54 \pm 0.01, \quad 0.66 \pm 0.01$ and $0.81 \pm 0.02$ for triglycerides in euthyroid, simple goiter and non-toxic nodular goiter, respectively (Tab.1 and Fig.2). Total lipids and triglycerides increased in camels with simple goiter $(\mathrm{P}<0.05)$, but in camels with nodular goiter there were a higher increase $(\mathrm{P}<0.01)$ in total lipids, cholesterol and triglycerides compared with healthy camels. 


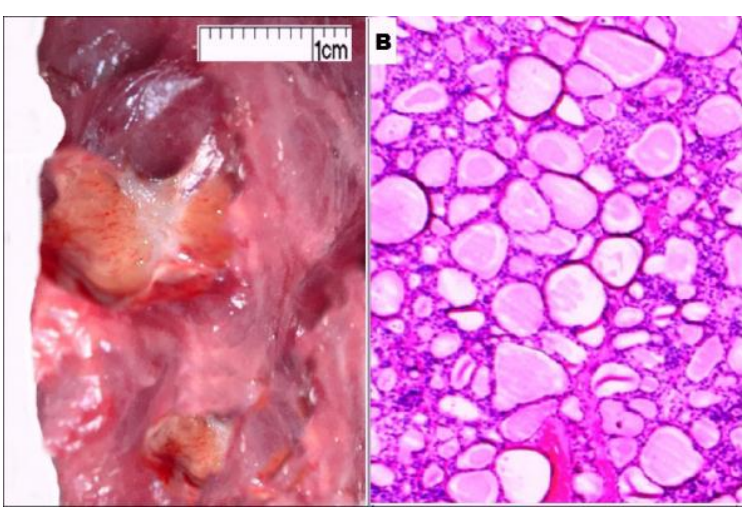

Graph 1:

A: Gross appearance of non-toxic nodular goiter: Lobs showed solitary nodules, which appeared semi-spherical, encapsulated lesion that was well demarcated from the surrounding thyroid

B: Simple goiter: Several follicles were mildly irregular in shape and varying in size (H\&E, x100)

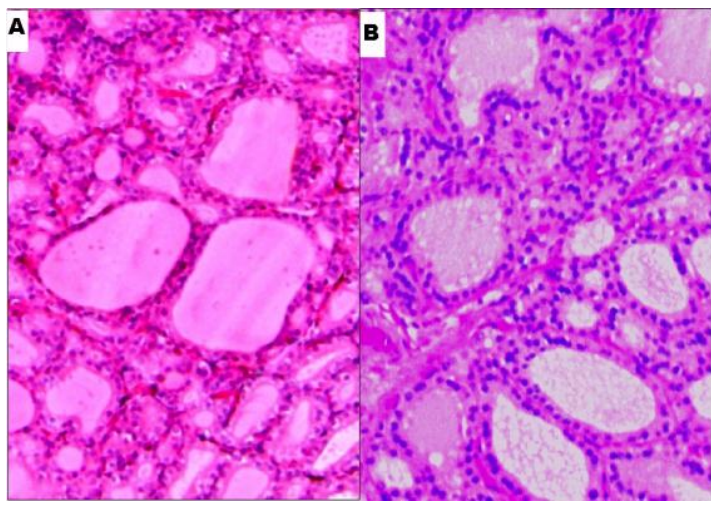

Graph 2:

A: Simple goiter: Some follicles were enlarged and lined by flattened epithelium and other follicles small and lined by columnar epithelium. (H\&E, x200)

B: Simple goiter: slight hyperplasia of the epithelial cells and the follicles are filled with lightly pale stained vacuolated colloid (H\&E, $\mathrm{x} 200$ )

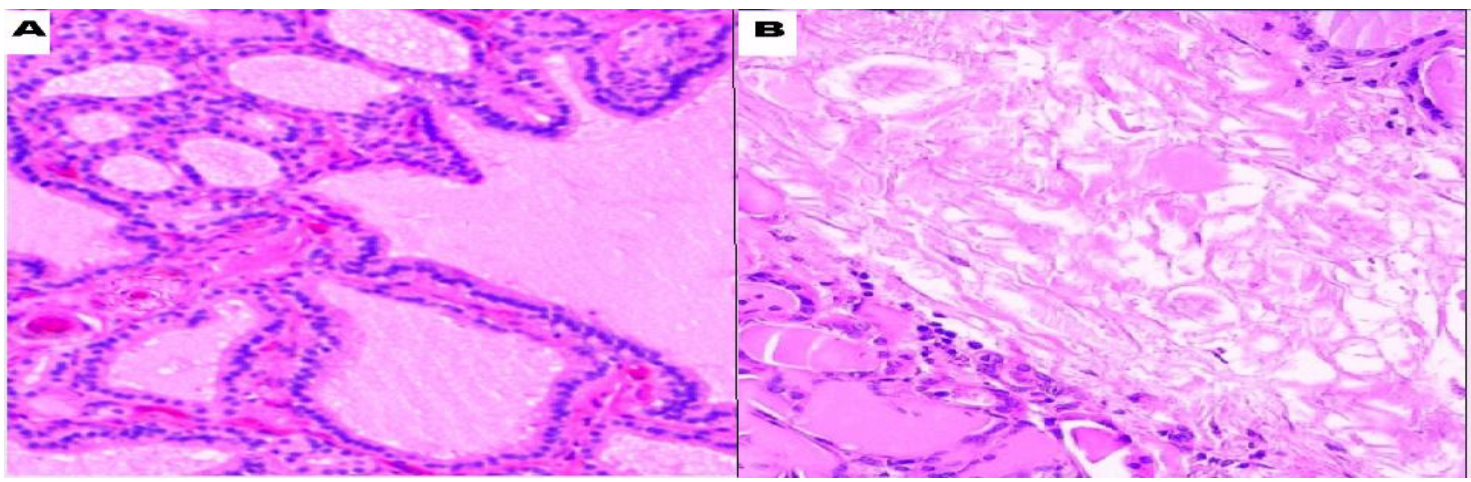

\section{Graph 3:}

A: Non-toxic nodular goiter: follicles were diffusely enlarged and dilated with papillary projections, lined with hyperplastic epithelium and vacuolated cytoplasm (H\&E, x200)

B: Non-toxic nodular goiter: follicles are lined by flattened to hyperplastic epithelium. Connective tissue proliferation separating the follicles and containing degenerated follicles (H\&E, x200)

Table 1: Thyroid hormones and lipid profile in camels with normal and abnormal thyroid gland.

\begin{tabular}{llll}
\hline Parameter & $\begin{array}{c}\text { Normal } \\
\mathrm{G} 3, \mathrm{~N}=10\end{array}$ & $\begin{array}{c}\text { Simple goiter } \\
\mathrm{G} 1, \mathrm{~N}=10\end{array}$ & $\begin{array}{c}\text { Non-toxic nodular goiter. } \\
\mathrm{G} 2, \mathrm{~N}=8\end{array}$ \\
\hline $\mathrm{T}_{3}(\mathrm{nmol} / \mathrm{l})$ & $1.21 \pm 0.04$ & $1.11 \pm 0.05^{\mathrm{NS}}$ & $0.89 \pm 0.03 * *$ \\
\hline $\mathrm{T}_{4}(\mathrm{nmol} / \mathrm{l})$ & $79.6 \pm 2.14$ & $76.4 \pm 2.34^{\mathrm{NS}}$ & $68.1 \pm 1.25^{* *}$ \\
\hline Total lipids $(\mathrm{mg} / \mathrm{dl})$ & $351.1 \pm 6.7$ & $379.4 \pm 5.6^{*}$ & $455.2 \pm 5.9^{* *}$ \\
\hline Cholesterol $(\mathrm{mmol} / \mathrm{l})$ & $0.92 \pm 0.03$ & $0.94 \pm 0.03^{\mathrm{NS}}$ & $1.21 \pm 0.04 * *$ \\
\hline Triglycerides $(\mathrm{mmol} / \mathrm{l})$ & $0.54 \pm 0.01$ & $0.66 \pm 0.01^{*}$ & $0.81 \pm 0.02^{* *}$ \\
\hline
\end{tabular}

*, ** significantly different from G3 (P < 0.05 and 0.01 , respectively). ${ }^{\text {NS }}$ : Non significantly different from G3 $(\mathrm{P}>0.05)$. 


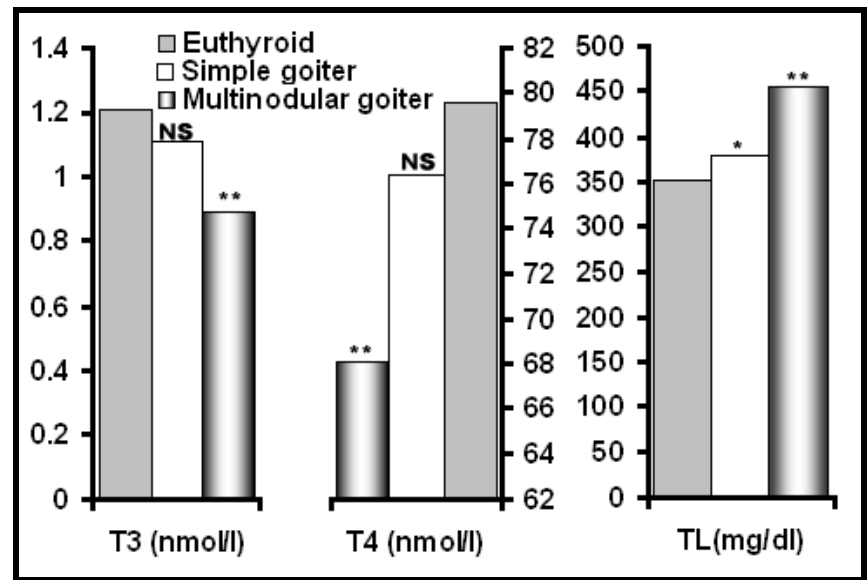

Fig. 1: levels of blood serum thyroid hormones and total lipids in camels with normal and abnormal thyroid gland.

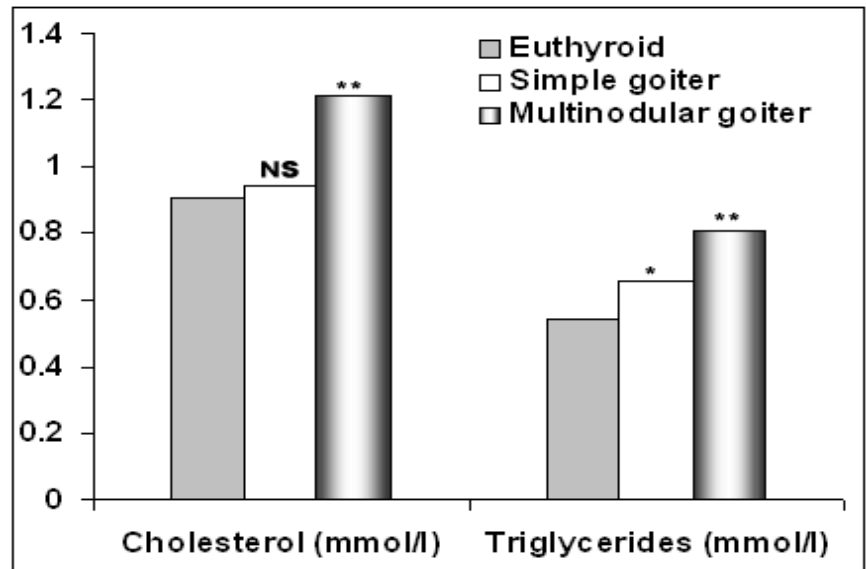

Fig. 2: levels of blood serum cholesterol and triglycerides in camels with normal and abnormal thyroid gland.

\section{DISCUSSION}

In camels, the location of thyroid gland in the body is similar to other large animals (Tefera, 2004). The gland appeared reddish brown in color, which is in concordance with the findings of Kausar and Shahid (2006) and Ahmad and Yousefi (2012).

In the present study, the histopathological changes in camel thyroid gland are similar to the previous reports of Tageldin et al. (1985), Abu Damir et al. (1990), Barsham et al. (2004) and Rejeb et al. (2011). The presence of a goiter reflects impaired synthesis of thyroid hormone, often caused by insufficient iodine in the diet. With the initial rise in TSH, there is follicular hyperplasia and hypertrophy with increased thyroid mass (McGavin et al., 2001). Whatever the cause for impaired thyroid hormone synthesis, the follicular epithelium adapts by becoming more sensitive to levels of TSH, with resultant increase in thyroid size and cellular activity to overcome the mild impairment (Kaneko, 2008). The nodular goiter of the thyroid gland is the most common cause for enlargement of the thyroid. Multinodular goiters are usually derived from simple diffuse goiters over many years (Jones et al., 1997).
The recorded mean values of blood serum T4 and T3 concentrations (nmol/l) in normal dromedary camels were $79.6 \pm 2.14$ and $1.21 \pm 0.04$ respectively. These values were lower than those reported by Wasfi, et al. (1987) in Saudi Arabian camels who recorded values of $17.92 \pm 1.19 \mu \mathrm{g} / \mathrm{dl} \quad(230.63 \pm 15.32 \mathrm{nmol} / \mathrm{l})$ and $9.33 \pm 1.15 \mathrm{ng} / \mathrm{ml}(1.43 \pm 0.18 \mathrm{nmol} / \mathrm{l})$ as normal camel serum for T4 and T3 levels respectively. Probably the difference in management, feeding and iodine concentrations in the diet are responsible for this reduction (Kaneko, 2008). Iodine deficiency was previously recorded in Assiut governorate (Abdou et al., 1967).

On the other hand, the mean concentrations of T4 in affected camels in the current study were similar to those reported by Barsham (2000) in goiterogenic areas in Sudan. The author found that the mean concentrations of $\mathrm{T} 4(\mathrm{nmol} / \mathrm{l})$ in camels in Idd Elfursan and Zalingei regions in Sudan were $80.48 \pm 25.1$ and $83.09 \pm 25.55$ respectively. Lower values were reported by the author for camels in Nyala region which recorded a mean value of $57.37 \pm 18.30 \mathrm{nmol} / \mathrm{l}$. The values were also lower than those reported by Abu Damir et al. (1990) for normal and camels with clinical and subclinical goiter in the Kordofan region of the Sudan. Higher mean values of 
T3 (nmol/l) were recorded by Barsham (2000) which were $1.68 \pm 0.61,1.62 \pm 0.65$ and $1.88 \pm 1.12$ for camels reared in Nyala, Idd Elfursan and Zalingei regions in Sudan respectively.

The lipid profile in one-humped camels differed substantially from that of other ruminants (Asadi et al., 2008). The over all mean concentrations of blood serum total lipids, cholesterol and triglycerides in camels in the current work are lower than those reported for other animal species (Mills and Taylaur, 1971; Kerr, 2002, Latimer et al., 2003 and Bruss, 2008) and slightly lower than those reported previously for camels (Wasfi et al., 1987; Abu Damir, et al., 1990; Nazifi and Maleki, 1998; Mohamed and Hussein, 1999; Barsham, 2000; Nazifi et al., 2000 and Mohamed et al., 2006). These differences in concentrations of blood serum lipids in normal camels might be related to the variation in the environment, management and feeding behaviour (Kerr, 2002 and Latimer et al., 2003). On the other hand, values of total lipids in healthy camels in the current work concur with those reported in camels by Tajik et al. (2013). Results may be useful in the evaluation of metabolic disorders in camels (Asadi et al., 2008).

In the current work, total lipids and triglycerides increased in camels with simple goiter, but in camels with nodular goiter, there were an increase in total lipids, cholesterol and triglycerides compared with healthy camels. Frank et al. (2003) reported higher plasma triglyceride concentrations following thyroidectomy in horses. In addition, a linear increase in total cholesterol levels has been observed with hypothyroidism (Asvold et al., 2007).

Thyroid hormones influence the major metabolic pathways and play a crucial role in the regulation of mitochondrial oxidative metabolism of protein, carbohydrate and lipid by increasing the basal energy expenditure (Kaneko, 2008). With specific view to lipid metabolism, thyroid hormones affect synthesis, mobilization and degradation of lipids (Danese et al., 2000 and Pucci et al., 2000). The participant effects of thyroid hormones on lipid metabolism include enhanced utilization of lipid substrates, increase in the synthesis and mobilization of triglycerides stored in adipose tissue, increase in the concentration of non-esterified fatty acids and increase of lipoproteinlipase activity (Miettinen, 1968; McGavin et al., 2001; Duntas, 2002; Frank et al., 2003 and Shavdatuashvili, 2005).

Thyroid hormones induce the 3-hydroxy-3methylglutaryl-coenzyme A (HMG-CoA) reductase, which is the first step in cholesterol biosynthesis (Hudig et al., 1998). Thyroid hormones can influence lipid metabolism by increasing cholesteryl ester transfer protein (CETP) activity, which exchanges cholesteryl esters from triglyceride to the opposite direction (Lagrost et al., 1994). Subclinical hypothyroidism associated with lipid disorders was reported by Duntas (2002) which characterized by elevated total lipids, triglycerides and cholesterol levels. The serum cholesterol level generally changes inversely with thyroid activity (Bruss, 2008), however, there are some contradictory findings regarding the relationship of serum thyroid hormones with cholesterol and triglycerides in camels. Nazifi et al. (2009) found a significant positive correlation between serum thyroid hormones and cholesterol in male dromedary camels.

It can be concluded that subclinical thyroid disorders and the concomitant hypothyroidism is associated with lipid disturbances that are characterized by elevated total lipids, cholesterol and triglycerides, in camels.

\section{REFERENCES}

Abdou, I.A.; Ali, H.E.; Bassioni, A.B.; Nafie, A.M. and Abde-Kader, M.S. (1967): Nutritional deficiencies, goiter, dental caries and parasitic infestations among school children in rural and urban areas of Assiut and Aswan Governorates, Bulletin of Nutrition institute, Cairo, Egypt, 111: 106.

Abu Damir, H.; Barri, ME.; Tageldin, MH. and Idris, OF. (1990): Clinical and subclinical colloid goitre in adult camels (Camelus dromedarius) at Kordofan region of Sudan. Br. Vet. J. 146: 219-27.

Ahmad, P.S.J. and Yousefi, M.H. (2012): Anatomical and histological study on thyroid gland in one humped camel (Camelus dromedarious) Journal of Veterinary Research; 67: 273-278.

Asadi, F.; Shahriari, A.; Asadian, P.; Pourkabir, M. and Samadaei, M. (2008): Composition and electrophoretic mobility of plasma lipoproteins of dromedary camels (Camelus dromedarius). Am. J. Vet. Res. 69: 880-885

Asvold, B.O.; Vatten, LJ.; Nilsen, TI. and Bjoro, T. (2007): The association between TSH within the reference range and serum lipid concentrations in a population-based study. Eur J. Endocrinol. 156: 181-186.

Barsham, M.A. (2000): Some biochemical and histopathological Alterations associated with hypothyroidism in camels (Camelus dromedarius). M.Vet Sc. Thesis, Faculty of Veterinary Science, University of Khartoum.

Barsham, M.A.; ElBagir, N.M. and Barri, M.E.S. (2004): Haematological and histopathological alterations in sodium thiocyanate-induced hypothyroid camels (Camelus dromedarius). Pakistan Journal of Biological Sciences, 2: 197-200. 
Bourdoux, P.P.; Ermans, A.M.; Mukalay, A.; Filletti, $S$. and Vigneri, R. (1996): Iodine-induced thyrotoxicosis in Kivu, Zaire, The Lancet, 347, 552-553.

Brody, T. (1999): Nutritional Biochemistry, 6th ed., Academic Press, New York, PP. 371.

Bruss, ML. (2008): Lipids and ketones. In: Kaneko JJ, Harvey JW, Bruss ML (Eds.). Clinical biochemistry of domestic animals. 6th ed. New York, USA: Academic Press Inc.pp 81116.

Danese, M.D.; Ladenson, P.W.; Meinert, C.L. and Powe, N.R. (2000): Effect of Thyroxine Therapy on Serum Lipoproteins in Patients with Mild Thyroid Failure: A Quantitative Review of the Literature. The Journal of Clinical Endocrinology and Metabolism 85: 2993-3001.

Duntas, LH. (2002): Thyroid disease and lipids. Thyroid. 12: 287-293.

Eshratkhah, B.; Sadaghian M. and Eshratkhah S. (2009): Relationship between the blood thyroid hormones and lipid profile in Moghani sheep: Influence of age and sex. Comp Clin Pathol 19: 15-20.

Fernandez, M.L. (2001): Guinea Pigs as Models for Cholesterol and Lipoprotein Metabolism. J. Nutr. 131: 10-20.

Fletcher, M.J. (1968): A colorimetric method for estimating serum triglycerides. Clinica et Chimica Acta. 22 393-397.

Frank, N.; Sojka, J.E. and Latour, M.A. (2003): Effects of hypothyroidism and withholding of feed on plasma lipid concentrations, concentration and composition of very-lowdensity lipoprotein, and plasma lipase activity in horses. Am. J. Vet. Res. 64: 823-828.

Hudig, F.; Meijssen, S. and Wiersinga, WM. (1998): Effects of triiodothyronine and amiodarone on the promoter of the human LDL receptor gene. Biochem Biophys Res Commun. 249: 517-21.

Jones, T.C.; Hunt, R.D. and King, N.W. (1997): Veterinary Pathology, $6^{\text {th }}$ ed., Williams and Wilkins, Baltimore, Philadelphia, London. PP. 1232.

Kaneko, JJ. (2008): Thyroid function. In: Kaneko JJ, Harvey JW, Bruss ML (Eds.). Clinical biochemistry of domestic animals. $6^{\text {th }}$ ed. New York, USA: Academic Press Inc. pp 627-630.

Kausar, R. and Shahid, R.U. (2006): Gross and microscopic anatomy of thyroid gland of onehumped camel (Camelus dromedarius). Pakistan Vet. J., 2006, 26(2): 88-90.

Kerr, M.G. (2002): Veterinary Laboratory Medicine 2nd ed. Blackwell Science, UK.

Lagrost, L. (1994): Regulation of cholesteryl ester transfer protein (CETP) activity: review of in vitro and in vivo studies. Biochim Biophys Acta. 1215: 209-236.
Latimer, K.S. (2011): Duncan and Prasse's Veterinary Laboratory Medicine: Clinical Pathology $5^{\text {th }}$ ed. Wiley, John \& Sons, Incorporated

Latimer, K.S.; Prasse, K.W. and Mahaffey, E.A. (2003): Proteins, lipids and carbohydrates. In Veterinary laboratory Medicine: Clinical Pathology. $4^{\text {th }}$ ed. Ames, Lowa State Univ Press. pp. 162-192.

McGavin, M.D.; Carleton, W.W. and Zachary, J.F. (2001): Thyroid gland, In: Special Veterinary Pathology, $3^{\text {rd }}$ ed., Mosby Co., St Lois, London, Philadelphia. Pp 295-305.

Miettinen, T.A. (1968): Mechanism of serum cholesterol reduction by thyroid hormones in hypothyroidism. J. Lab. Clin. Med. 4: 537547.

Mills, G.L. and Taylaur, C.E. (1971): The distribution and composition of serum lipoproteins in eighteen animals. Comp. Bioch. And Physiol. 40B, 489-501.

Mohamed, A.M.; Abd Ellah, M.R.; Abou El-Ella, Gh.A. and Osman, F.A. (2006): The influence of some nematode parasitism on lipid metabolism and lipoprotein profile in dromedary camel (Camelus dromedaries). Proceedings of the 12th Sci. Cong., 10-12 Dec. 2006. Fac. Vet. Med., Assist Univ. Egypt. 265-275

Mohamed, H.A. and Hussein, A.N. (1999): Studies on normal haemtological and serum biochemical values of the 'Hijin' racing camels (Camelus dromedarius) in Kuwait. Veterinary Research Communications, 23: 241-248.

Mohebbi-Fani, M.; Nazifi, S. and Rowghani, E. (2009): Thyroid hormones and their correlations with serum glucose, beta hydroxybutyrate, nonesterified fatty acids, cholesterol and lipoproteins of high-yielding dairy cows at different stages of lactation cycle. Comp Clin Path 18: 211-216.

Nazifi, S. and Maleki, K. (1998): Biochemical analysis of serum and cerebrospinal fluid in clinically normal adult camel (Camelus dromedaries). Research in Veterinary Science, 65: 83-84

Nazifi, S; Nikahval, B.; Mansourian, M.; Razavi, S.M.; Farshneshani, F.; Rahsepar, M.; Javdani, M. and Bozorgi, H. (2009): Relationships between thyroid hormones, serum lipid profile and erythrocyte antioxidant enzymes in clinically healthy camel (Camelus dromedarius) Revue Méd. Vét, 160, 3-9.

Nazifi, S.; Gheisari, HR.; Poorkabir, MA. and Saadatfar, S. (2000): Serum lipids and lipoproteins in clinically healthy male Camels (Camelus dromedarius). Vet Res Commun. 24: 527-531.

Pucci, E.; Choate, L. and Pinchera, A. (2000): Thyroid and lipid metabolism. International Journal of Obesity and Related Metabolic Disorders. 24 Suppl 2: S109-112. 
Rejeb, A.; Amara, A.; Rekik, M.; Rezeigui, H. and Crespeau, F. (2011): Histomorphometry and hormone secretion of the thyroid gland of the dromedary (Camelus dromedarius). Journal of Camelid Science 4: 10-22.

Schillhorn, T.W. and Loeffler, I.K. (1990): Mineral deficiency in ruminants in Subsaharan Africa, Trop. Anim. Hlth. Prod; 22: 197-205.

Shavdatuashvili, T. (2005): Lipoprotein profile and endothelial function in patients with subclinical and overt hypothyroidism. Georgian Medical News. 129: 57-60.

Stein, E.A. (1986): Quantitative enzymatic clorimetric test for determination of plasma total lipid and cholesterol. In Tietz, N.W. (ed.) Test book of clinical chemistry. W.B. Saunders, Philadelphia. pp. 879-886.

Tageldin, MH.; Sid Ahmed el Sawi, A. and Ibrahim, $S G$. (1985): Observations on colloid goiter of dromedary camels in the Sudan. Rev Elev Med Vet Pays Trop. 38: 394-397.

Tajik, J.; Sazmand, A.; Moghaddam, S.H.H. and Rasooli, A. (2013): Serum concentrations of thyroid hormones, cholesterol and triglyceride, and their correlations together in clinically healthy camels (Camelus dromedarius): Effects of season, sex and age. Veterinary Research Forum. 4: 239-243.

Tefera, M. (2004): Observations on the Clinical Examination of the Camel (Camelus dromedarius) in the Field. Tropical Animal Health and Production. 36: 435-449.

Wasfi, IA.; Hafez, AM.; El Tayeb, FM. and El Taher, $A Y$. (1987): Thyroid hormones, cholesterol and triglyceride levels in the camel. Res Vet Sci. 42: 418.

Zlatkis, A. and Zak, B. (1969): Study of a new cholesterol reagent. Analyt. Biochem. 29: 143-148.

\section{قصور الغدة الدرقية الخفي ومدي ارتباطه بصورة الدهون والتغيرات الهستوباثولوجية في الغدة الألدقية في الجمال وحيدة السنام \\ سعيزة أحمد سنوسي ، محمد حجازي راتب ، سحر أحد أبوالوفا ، لمباء أبو الحسن محدد ، مصطفى أحمد صالح Email: M M mohmmed77@yahoo.com \\ Assiut University web-site: www.aun.edu.eg}

قصور الغدة الدرقية تحت الإكلينيكي هو النوع الثائع في الحيو انات. هذه الدراسة تستهدف تحديد العلاقة بين اضطر ابات الغدة الدرقية

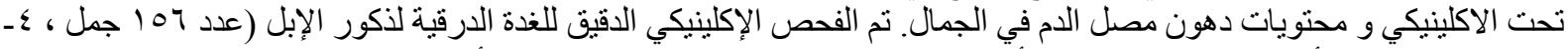

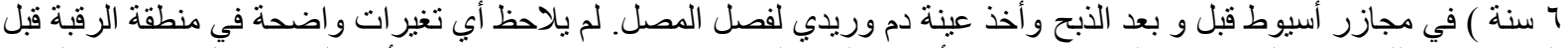

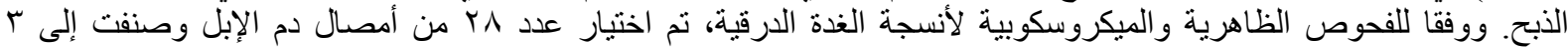

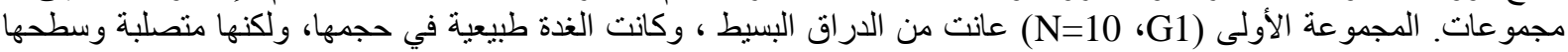

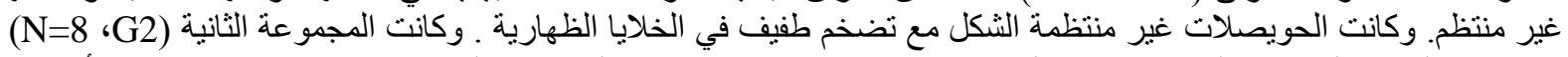

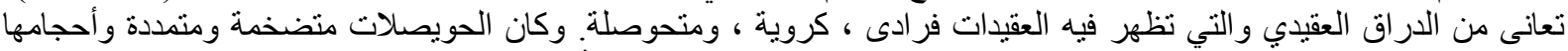

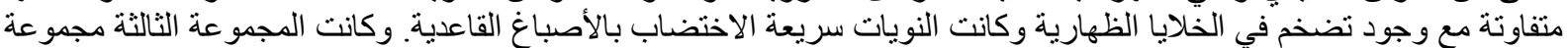

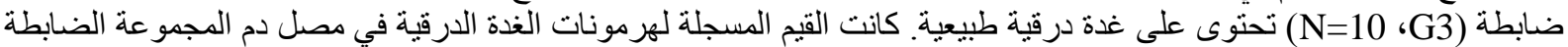

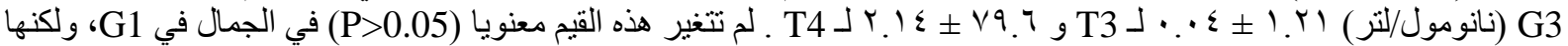

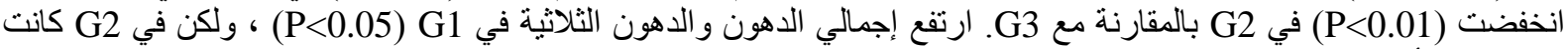

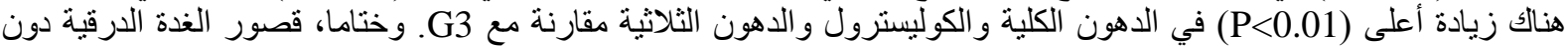
الإكلينيكي في الجمال يتر افق باضطر ابات الدهون حيث يتميز بارتفاع قيم الدهون الكلية والدهون الثنلاثية و الكوليسترول. 